DOI: $10.14720 /$ aas.2016.107.2.01

Agrovoc descriptors: fertilizers, inorganic fertilizers, foliar application, titanium dioxide, new technology, growth, crop yields, yield components, barley

Agris category code: F04

\title{
Impact of foliar application of nano micronutrient fertilizers and titanium dioxide nanoparticles on the growth and yield components of barley under supplemental irrigation
}

\author{
Mohsen JANMOHAMMADI*, Tahereh AMANZADEH, Naser SABAGHNIA, Shahryar DASHTI
}

Received September 09, 2015; accepted May 22, 2016.

Delo je prispelo 09. septembra 2015, sprejeto 22. maja 2016.

\begin{abstract}
Nano-fertilizers are new generation of the synthetic fertilizers which contain readily available nutrients in nano scale range. Nano fertilizers are preferred largely due to their efficiency and environment friendly nature compared to conventional chemical fertilizers. To evaluate the effects of foliar spray of micronutrient nano-fertilizer (iron and zinc) and nano-titanium dioxide $\left(\mathrm{nTiO}_{2}\right)$ solution on grain yield and its components in barley under supplemental irrigation conditions, a field experiment was carried out in the semi-arid highland region of Maragheh, Iran. Barley plants were separately treated with of chelated nano-scale zinc oxide $(\mathrm{ZnO})$ and ferric oxide $\left(\mathrm{Fe}_{2} \mathrm{O}_{3}\right)$ suspensions during tillering stage, booting and milky stages Results revealed that days to anthesis and maturity significantly increased after application of both nanofertilizers. Furthermore, a considerable improvement was observed in grain mass, spike length, number of the grains per spike, chlorophyll content, grain yield and harvest index by application of nano-fertilizer. However the impact of nano zinc fertilizer was more prominent than iron. Foliar application of $\mathrm{nTiO}_{2}$ positively affected some morphophysiological characteristics like as days to anthesis, chlorophyll content and straw yield. The results suggest that the delivery of $\mathrm{Zn}$ into barley seedling through spray of nanofertilizer can be an efficient nutrient management strategy in semi-arid regions. Overall, our result indicated that the integration of nanotechnology in fertilizer products can improve fertilizer use efficiency and significantly increase of barley yield. However, plant response to nanoparticles significantly depend on concentration and time of application as well as size, shape, and surface functionalization of the particles.
\end{abstract}

Key words: chemical fertilizer, exogenous application, nano ferric oxide, $\mathrm{TiO}_{2}$ nanoparticles, nano zinc oxide

\section{IZVLEČEK}

VPLIV FOLIARNEGA DODAJANJA NANO MIKRO GNOJIL IN NANODELCEV TITANOVEGA DIOKSIDA NA RAST IN PRIDELEK JEČMENA V RAZMERAH NAMAKANJA

Nano gnojila so nova generacija sintetičnih gnojil, ki vsebujejo hitro razpoložljiva hranila v nano območju. Priljubljenost nano gnojil temelji na njihovi učinkovitosti in okolju prijazni naravi v primerjavi $\mathrm{s}$ konvencionalnimi mineralnimi gnojili. $\mathrm{Za}$ ovrednotenje učinka foliarnega pršenja $\mathrm{z}$ mikro nano gnojili (železo in cink) in raztopino nano titanovega dioksida $\left(\mathrm{nTiO}_{2}\right)$ na pridelek zrnja ječemena in njegove komponenete je bil na semiaridnem višavskem območju Maragheha, Iran izveden poljski poskus ob sočasnem namakanju. Rastline ječmena so bile ločeno tretirane s suspenzijo nano delcev cinkovega $(\mathrm{ZnO})$ in železovega oksida $\left(\mathrm{Fe}_{2} \mathrm{O}_{3}\right)$ v fazah razraščanja, bilčenja in mlečne zrelosti. Rezultati so pokazali, da se je število dni do anteze in zrelosti značilno povečalo po uporabi obeh nano gnojil. Še več, po uporabi nano gnojil je bilo opazno znatno izboljšanje v masi zrnja, dolžini klasa, številu zrn na klas, vsebnosti klorofila, pridelku zrnja in $\mathrm{v}$ žetvenem indeksu.Večji učinek na te lastnosti je imela uporaba cinkovega gnojila. Foliarno dodajanje $\mathrm{nTiO}_{2}$ je pozitivno vplivalo na nekatere morfo-fiziološke lastnosti kot so število dni do anteze, vsebnost klorofila in pridelek slame. Rezultati nakazujejo, da je vnos Zn v kalice ječmena s pršenjem nano gnojil učinkovit način uravnavanja hranil v semi-aridnih območjih. Ti rezultati nakazujejo, da vključitev nanotehnologije v proizvodno gnojil lahko izboljša učinkovitost njihove uporabe in znantno poveča pridelek ječmena. Kakorkoli, odziv rastlin na nano delce je značilno odvisen od njihove koncentracije, časa uporabe, kot tudi od njihove velikosti, oblike in površinske funkcionalnosti.

Ključne besede: mineralna gnojila, zunanja uporaba, nano železov in cinkov oksid, semi-aridna območja, $\mathrm{TiO}_{2}$ nanodelci

\footnotetext{
Department of Agronomy and Plant Breeding, Agriculture College, University of Maragheh, East Azerbaijan, Iran; *correspponding author: mjanmohammadi@maragheh.ac.ir
} 


\section{INTRODUCTION}

Barley (Hordeum vulgare L.) is a major cereal grain. It was one of the oldest cultivated grains and now it is one of the most widespread cereals. Barley yield and quality predictions are of major interest to the growers and it is because of current consumer interest in nutrition and health. Improvement of the barley quality and quantity may help restore barley's status in the human diet. In Iran barley as second important crop and it has been estimated that its production in Iran is exceeded 3.2 million tones from an area of 1.6 million ha land (FAOSTAT. 2013). In Iran barley is used almost exclusively as animal feed. In northwest of Iran barley is planted almost on dryfarmed lands, located on mountain slopes.

However, the main reasons of low yield of barley in semi-arid regions of the Mediterranean basin are adverse environmental conditions, nutritional imbalance, cultivation of local cultivars with low potential yield and lack of other production inputs. Terminal drought and high temperature are two environmental phenomena frequency occurring during critical reproductive growth stage. Heat stress during anthesis and post-anthesis period can significantly decrease grain yield and quality in barley. Furthermore, climate change during the last decades intensified these abiotic stresses in rainfed areas, as increased the temperatures and changed the patterns of precipitation and water availability (Batisani and Yarnal, 2010). Although in barley production there are many management strategies for improving yield and grain quality, supplement irrigation and adequate plant nutrition, involving the application of fertilizers, especially micronutrient is seen as having a crucial role in food productivity/quality particularly in semi-arid area (Ryan et al., 2012). In order to achieves an acceptable grain yield in barley providing the micro and macro nutrients are fundamentals. Fertilizer management can intensely affect crop productivity in semi-arid region where the terminal drought stress is very prevalent, thus, the addition of nutrients can either enhance or decrease plants resistance to drought or have no effect at all, depending on the level of water availability (Boorboori et al., 2012; Fahad et al., 2014).

Accordingly, a balanced fertilization strategy with macro and micronutrients in plant nutrition is very imperative for crop production in this areas. Although micronutrients are needed in small quantities, they play vital roles in development of plants. The great importance of micronutrients is because of their stimulatory and catalytic effects on metabolic processes and their positive effects on yield and quality (Hänsch and Mendel, 2009; Marschner, 2012). However, among the micronutrients, iron is essential for crop growth and food production. Iron is involved in the production of chlorophyll, photosynthesis, mitochondrial respiration, hormone biosynthesis (ethylene, gibberellic acid, jasmonic acid), production and scavenging of reactive oxygen species and osmoprotection (Hänsch and Mendel, 2009). Also it is a component of many important enzymes associated with energy transfer, nitrogen reduction and fixation, lignin formation and pathogen defense. Fahad et al. (2014) reported that iron deficiency is a dominant problem in semi-arid zone with alkaline soils. Furthermore, some soils with low organic matter also may be iron-deficient. In these area foliar spray has been recommend as a more efficient way to correct iron deficiency (Galavi et al. 2012; Boorboori et al., 2012).

Moreover, zinc is a necessary component of various enzyme systems for energy production, protein synthesis, energy production, maintains the structural integrity of biomembranes and growth regulation (Hänsch and Mendel, 2009). Like to iron, zinc deficiencies are mainly found on sandy soils low in organic matter and on alkaline soils. Uptake of zinc also is adversely affected by high $\mathrm{pH}$, high levels of available phosphorus and iron in soils (Ghasemi-Fasaei and Ronaghi, 2008).

In the last few years, some researchers tried to examine the potential of nanotechnology to improve fertilizer use efficiency. These efforts led to design and development of nano-fertilizer. Nanotechnology-based fertilizers could be more soluble or more reactive than their bulk counterparts (Nair et al., 2010; DeRosa et al., 2010; Naderi and Danesh-Shahraki, 2013; Rameshaiah and Jpallavi, 2015). Application of nano-fertilizers may improve solubility and dispersion of insoluble nutrients in soil, reduce nutrient immobilization (soil fixation) and increase the bio-availability (Naderi and Danesh-Shahraki, 
2013). Nano formulated fertilizers can be easily absorbed by plants and they may exhibit prolonged effective duration of nutrient supply in soil or on plant (Rameshaiah and Jpallavi, 2015). Zhang et al. (2006) investigated the effects of slow/controlledrelease fertilizers cemented and coated by nanomaterials on crop. It was found that these nanocomposites were safe for wheat seed germination, emergence and growth of seedlings and they can provide a regulated, responsive and on time delivery of nutrients to plants. Also several studies show that exogenous application of some nanoparticle can significantly improve plant growth (Mandeh et al., 2012; Song et al., 2013). Titanium dioxide nanoparticles $\left(\mathrm{nTiO}_{2}\right)$ are promising as efficient nutrient source for plants to improve biomass production due to enhanced the nitrogen assimilation, photoreduction activities of photosystem II and electron transport chain, scavenging of reactive oxygen species, and (Morteza et al., 2013; Raliya et al., 2015). In the northwestern part of Iran zinc and iron deficiencies are nutritional disorders in most of the plants grown in dryland condition. Since these two nutrients are meaningfully involved in grain yield production and their deficiency may occur frequently in semi-arid regions; the present investigation was undertaken to improve understanding about the foliar application of nano chelated iron and zinc fertilizers as well as $\mathrm{nTiO}_{2}$ on yield and yield components of winter barley.

\section{MATERIALS AND METHODS}

The trials presented here were carried out at the research field, College of Agriculture, University of Maragheh $\left(37^{\circ} 23^{\prime} \mathrm{N} ; 46^{\circ} 16^{\prime} \mathrm{E}\right)$, Maragheh, in northwest of Iran (Figure 1). Maragheh has an average annual rainfall of $375 \mathrm{~mm}$ consisting of $73 \%$ rain and $27 \%$ snow falling through winter and early spring. Based on Koppen's classification, this region has semi-arid and cold temperate. Some climatic parameters during this research are given in Table 1. The soil texture of the experimental site is sandy loam, comprising of $53 \%$ sand, $31 \%$ silt and $16 \%$ clay. It contains $0.14 \%$ organic matter (OM) with a pH of 7.87, with electrical conductivity $(\mathrm{EC})=1.96 \mathrm{ds} \mathrm{m}^{-1}, 0.058 \%$ nitrogen (N) and 5.67 available phosphorus $\left(\mathrm{mg} \mathrm{kg}^{-1}\right)$. Soils of the arid and semi-arid zones are rich in potassium, as amount of available potassium $(\mathrm{K})$ was $342 \mathrm{mg} \mathrm{kg}^{-1}$.

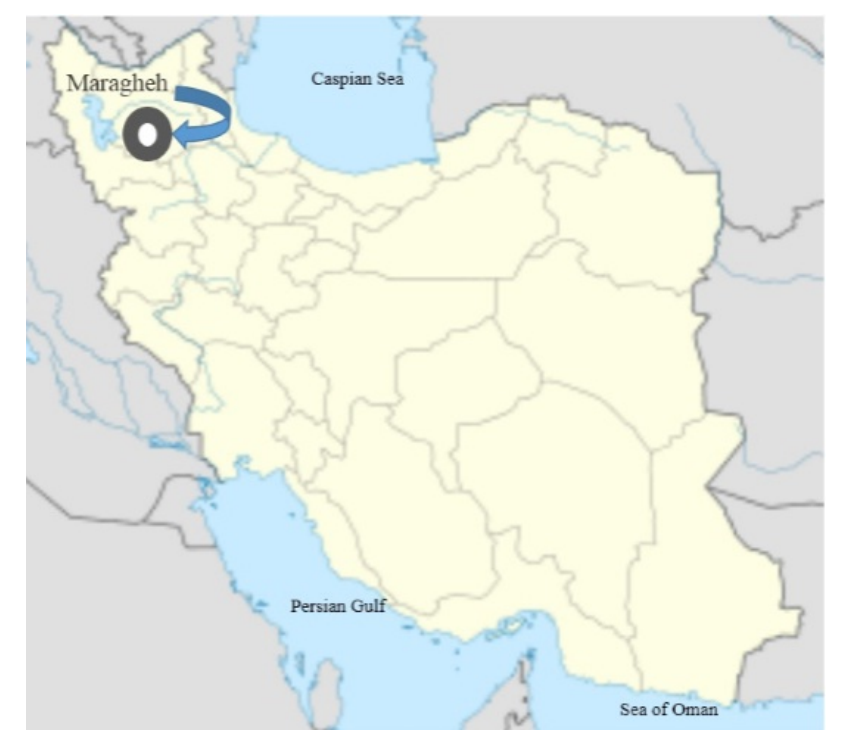

Figure 1: The experimental field was located in Maragheh which is a town in East Azerbaijan Province, North West of Iran. 
The field was mouldboard-ploughed and twice disked before seed sowing. After primary and secondary tillage, the seeds were hand planted on 3 December, 2014. The facultative barley (Hordeum vulgare 'Sahand') was used in the experiment. The cultivar is a two-row barley with approximately long awns that is cold tolerant and appropriate for highlands. Each plot was $9 \mathrm{~m}^{2}$ consisting of eight rows, $3 \mathrm{~m}$ long and $10 \mathrm{~cm}$ apart. Seeds were sown $4 \mathrm{~cm}$ apart at $5 \mathrm{~cm}$ depth. Phosphorus was applied at the rate of $30 \mathrm{~kg} \mathrm{ha}^{-1}$ as basal dose and urea $(46.6 \% \mathrm{~N})$ as nitrogen fertilizer was utilized at the rate of $100 \mathrm{~kg} \mathrm{ha}^{-1}$. It was added into two equal portions as rational application, the first part was utilized in sowing time and the second part was applied in jointing stage. There was no incidence of pest or disease on plants during the experiment. Weeds were controlled by systemic selective chlorophenoxy herbicides including 2, 4-D and MCPA. Plants were grown under rain-fed condition that received natural rainfall and only two supplemental irrigations (surface or flood irrigation) were applied during jointing and heading stages. The amount of irrigation water was calculated to restore water content in the root zone to field capacity. Depth of net irrigation water fraction was $\sim 110 \mathrm{~mm}$. All other inputs and agronomic practices were carried out uniformly.

Table 1: Monthly temperature and precipitation during the growing season in 2014-2015.

\begin{tabular}{lccccc}
\hline & $\begin{array}{c}\text { maximum temperature } \\
\left({ }^{\circ} \mathrm{C}\right)\end{array}$ & $\begin{array}{c}\text { Minimum } \\
\text { temperature }\left({ }^{\circ} \mathrm{C}\right)\end{array}$ & Humidity $(\%)$ & $\begin{array}{c}\text { Total precipitation } \\
(\mathrm{mm})\end{array}$ & ET $_{0}$ \\
\cline { 2 - 6 } December & 7.36 & 2.15 & 61.25 & 14.46 & 64.38 \\
November & 9.08 & 3.53 & 48.64 & 31.24 & 76.16 \\
January & 8.07 & -2.26 & 59.53 & 22.72 & 52.23 \\
February & 10.07 & -0.21 & 59.55 & 21.5 & 61.24 \\
March & 13.49 & 2.47 & 52.78 & 24.5 & 96.31 \\
April & 19.24 & 6.43 & 46.70 & 16.38 & 14.93 \\
May & 25.30 & 11.62 & 42.00 & 38.71 & 206.13 \\
June & 32.21 & 18.00 & 26.95 & 1.8 & 267.04 \\
July & 37.00 & 23.45 & 22.00 & 0.28 & 348.00 \\
\hline
\end{tabular}

$\mathrm{ET}_{0}=$ reference evapotranspiration,

The investigated treatments included micronutrient fertilizers (iron nano chelate, zinc nano chelate, control) and foliar application of titanium dioxide nanoparticles $\left(\mathrm{nTiO}_{2}\right)$ at two concentrations: 0 and $2000 \mathrm{ppm}$. Micronutrients nano-fertilizers applied three times during initiation of tillering stage, booting and milky stage. $\mathrm{nTiO}_{2}$ solution was sprayed on the plants leaves at the end of vegetative growth (double ridge stage) and during the inflorescence emergence (reproductive stage). Plants sprayed with distilled water served as the control. Treatments were applied according to randomization complete blocks design (RCBD) under factorial with three replicates. Nanotitanium $\left(\mathrm{nTiO}_{2}\right)$ was purchased from the Pishgaman Nano, Iran. Nano chelated fertilizers were obtained from the Sepeher Parmis Company, Iran, which contained zinc oxide or iron oxide nanoparticles. Synthesized nano particles had been characterized morphologically by transmission electron microscopy (Figure 2). Chlorophyll content was measured by "SPAD 502" portable chlorophyll-meter system at the beginning of booting stage for fully expanded upper-canopy leaves. Crop phenology was monitored at 1-2 day intervals throughout the season and number of days from sowing to initiation of anthesis and day to maturity was determined. At maturity stage, yield contributing parameters and morphological traits, such as plant height, number of fertile tillers, straw mass, panicle length, number of grains/panicle, 1000 grain mass and grain yield evaluated. The statistical analysis of experimental data utilized the SAS program. Each experimental value was compared to its corresponding control. Statistical significance was accepted when the probability of the result assuming the null hypothesis, $\mathrm{p}$ is less than 0.05 (level of probability). Correlation analysis and principal component analysis (PCA), based on the rank correlation matrix and biplot analysis were performed by SPSS ver. 16, STATISTICA ver. 8 and Minitab ver.16. 

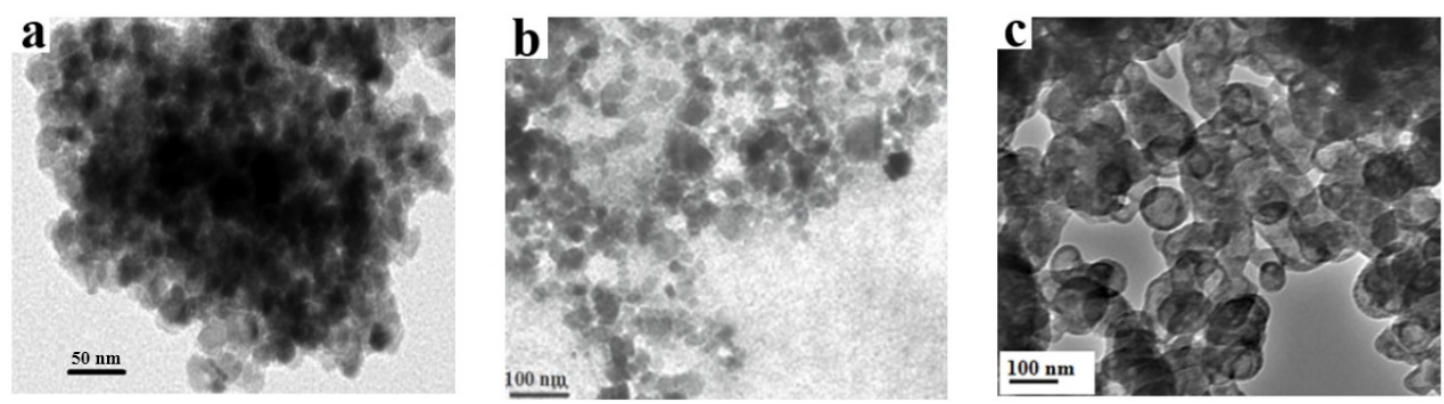

Figure 2: Transmission electron microscopy (TEM) micrograph of synthesized $\mathrm{TiO}_{2}$ nanoparticles (a), nano zinc oxide (b) and iron oxide nanoparticles (c) nanoparticles.

\section{RESULTS AND DISCUSSION}

The results pertaining to effect of nano-fertilizers and nano- treatments on morphological characteristics are depicted in Table 2. Variance analysis showed that plant height $(\mathrm{PH})$, peduncle length (PL) and stem diameter (SD) were not affected by foliar application of nano-fertilizers and $\mathrm{nTiO}_{2}$. Although the micronutrients could numerically increase plant height $(\mathrm{PH})$ up to $8 \%$ compared to control, this increase was not statistically significant. The similar trend was recorded for $\mathrm{nTiO}_{2}$ application. Although, these results differ from some published studies (Jam et al., 2011; Fahad et al., 2014), they are consistent with those of Abbas et al. (2009) who found that the various levels of $\mathrm{Zn}$ fertilizer not significantly affect the plant height. Based on the fact that the $\mathrm{Fe}$ and $\mathrm{Zn}$ have important roles in physiological and biochemical processes of development, it was predictable that application of micronutrients can increase the leaves growth and improve straw yield (Table 3).

Literature reports that the number of tillers per plant is an important yield component which varies considerably with variation in environmental conditions (seed-bed preparation, availability of soil moisture at sowing, nutrition managements, bird or insect damage on sown seeds, etc.) and with genotype. However, it seems that investigated variety tended to be more stable for tiller number. Likewise high planting density may affect this parameter. It appears that the number of tillers per plant has apparently high phenotypic plasticity under dense canopy, so that they cannot response to nutrient managements efficiently. These results are consistent with those of other studies suggesting that effects of foliar and soil application of $\mathrm{Fe}, \mathrm{Zn}, \mathrm{Cu}$ and $\mathrm{Mn}$ fertilizers on number of tiller was not statistically significant (Boorboori et al., 2012). Results from Table 2 show that foliar application with $\mathrm{Zn}$ and $\mathrm{Fe}$ did not increase the number of fertile tillers. Similarly $\mathrm{nTiO}_{2}$ application had no any significant effect on number of fertile tillers. It is encouraging to compare this figure with that found by Arora and Singh (2004) and Bouis (2003) who suggested that number of tiller in wheat and barley is controlled by genetic factors and nutrition has a minor effect on this trait. 
Table 2: Effect of foliar application of micro-nutrients and nano-titanium on some morphological traits of barley.

\begin{tabular}{lccccccc}
\hline \multirow{2}{*}{ micro-nutrients } & PH & SD & NTP & NFT & GWP & NGS & PL \\
\cline { 2 - 8 } control & $\mathrm{ns}$ & & $\mathrm{ns}$ & $\mathrm{ns}$ & ${ }^{*}$ & ${ }^{*}$ & ${ }^{*}$ \\
$\mathrm{Fe}$ & $68.00 \mathrm{a}$ & $22.65 \mathrm{a}$ & $3.58 \mathrm{a}$ & $1.91 \mathrm{a}$ & $0.64 \mathrm{~b}$ & $14.95 \mathrm{~b}$ & $12.46 \mathrm{a}$ \\
$\mathrm{Zn}$ & $72.95 \mathrm{a}$ & $23.07 \mathrm{a}$ & $3.63 \mathrm{a}$ & $2.09 \mathrm{a}$ & $0.71 \mathrm{ab}$ & $16.93 \mathrm{a}$ & $12.75 \mathrm{a}$ \\
\hline nano- titanium & $73.50 \mathrm{a}$ & $23.85 \mathrm{a}$ & $3.67 \mathrm{a}$ & $2.02 \mathrm{a}$ & $0.73 \mathrm{a}$ & $16.61 \mathrm{a}$ & $13.91 \mathrm{a}$ \\
non & $\mathrm{ns}$ & $\mathrm{ns}$ & $\mathrm{ns}$ & $\mathrm{ns}$ & $\mathrm{ns}$ & ${ }^{*}$ & ns \\
with & $71.66 \mathrm{a}$ & $22.66 \mathrm{a}$ & $3.47 \mathrm{a}$ & $1.92 \mathrm{a}$ & $0.72 \mathrm{a}$ & $15.38 \mathrm{~b}$ & $13.34 \mathrm{a}$ \\
$\mathrm{CV} \%$ & $71.52 \mathrm{a}$ & $21.77 \mathrm{a}$ & $3.79 \mathrm{a}$ & $2.10 \mathrm{a}$ & $0.68 \mathrm{a}$ & $16.95 \mathrm{a}$ & $12.71 \mathrm{a}$ \\
\hline
\end{tabular}

$\mathrm{PH}=$ plant height $(\mathrm{cm}), \mathrm{SD}=$ stem diameter $(\mathrm{mm}), \mathrm{NTP}=$ number of tillers per plants, $\mathrm{NFT}=$ number of fertile tillers, $\mathrm{GWP}=$ grain mass per plant $(\mathrm{g}), \mathrm{NGS}=$ number of grain per spike, $\mathrm{PL}=$ peduncle length $(\mathrm{cm})$. Mean values of the same category followed by different letters are significant at $p \leq 0.05$ level.

Result showed that foliar application of micronutrients considerably affected the thousand grains mass (TGW) and grain mass per plant (table 2 and 3). Application of zinc nano-fertilizer increased the grain mass up to $6 \%$ over to control. The higher thousand grain mass indicates increased individual grain sink strength. The sink strength can be depicted as the output of sink activity and sink size (Yang et al., 2003). Sink activity is controlled by enzymes involved in starch biosynthesis and degradation (Bihmidine et al., 2013). It is assumed that phytohormones, particularly cytokinins play a major role in increasing sink size by promoting cell division during the early phase of seed filling. However, more recent work has shown that grain mass and endosperm cell number in wheat are closely associated (Saalbach et al., 2014). Besides in cereals, endosperm cell number is regulated by assimilate supply during the first two weeks after anthesis (Yang et al., 2003). With regards to positive effects of micronutrients on spike length and chlorophyll content (Table 2), it appears that micronutrient application improved the grain mass through the increasing assimilate supply, levels of cytokinins and sink size.

Assessment of the grain number per spike (NGS) revealed that it affected by micronutrient and $\mathrm{nTiO}_{2}$ application with $95 \%$ confidence level. So that foliar application of the Fe and $\mathrm{Zn}$ improved grain number up to $11 \%$ and $13 \%$, respectively, in compared to control. This finding corroborates the ideas of Tarafdar et al. (2014), who suggested that application of zinc nano-fertilizer on pearl millet (Pennisetum americanum L.) significantly improved shoot length, root length, root area, chlorophyll content, total soluble leaf protein, plant dry biomass, and increased the grain yield by $37.7 \%$. On the other hand spray of $\mathrm{nTiO}_{2}$ increased grain number per spike up to $10 \%$ over to control. It is recognized that the grain number per spike is strongly depended on assimilates allocation to the spike and it is limited by postphloem assimilate supply (Saalbach et al., 2014). Nano-titanium dioxide $\left(\mathrm{nTiO}_{2}\right)$ with photocatalytic property can increase photosynthesis by promoting cyclic and linear photophosphorylation (Gao et al., 2013) and it can result in enhancement of photoassimilates supply in leaves (i.e., increasing source capacity). However, positive effect of $\mathrm{nTiO}_{2}$ on grain number per spike in this study corroborates these earlier findings of Rezaei et al. (2015). Although theoretically there are some compensating effects between grain number per spike and grain mass, in current study application of nano-fertilizers increased both parameters.

Investigation the effect of nano-fertilizer and $n \mathrm{TiO}_{2}$ on chlorophyll content (CHL) showed that both of them significantly affected this parameter with $99 \%$ confidence level. Different researchers feel that micronutrients play critical roles in the synthesis of chloroplast proteins and thus may interfere with chlorophyll synthesis. It has been revealed that lack of micronutrients inhibit the formation of chlorophyll through inhibition of protein synthesis (Marschner, 2012; Hänsch and Mendel, 2009). However, the findings of the current study do not support some result of Klingenfuss (2014), who reported that chlorophyll content of the $\mathrm{Zn}$ treatment was significantly smaller to the control. Besides the same research reported a positive effect of nano-titanium on 
chlorophyll content in wheat seedling. These findings further support the idea of Morteza et al., (2013) that foliar utilization of $\mathrm{nTiO}_{2}$ can improve plant growth and grain yield by facilitating the manufacture of pigments and transformation of light energy to active electron and chemical activity and increases photosynthetic efficiency.

Table 3: Effect of foliar application of micro-nutrients and nano- titanium on some morphological traits of barley.

\begin{tabular}{|c|c|c|c|c|c|c|c|c|}
\hline micro-nutrients & SL & TGW & DA & DM & $\mathrm{CHL}$ & GY & SY & $\mathrm{HI}$ \\
\hline control & $9.50 \mathrm{~b}$ & $26.96 \mathrm{~b}$ & $187.33 \mathrm{~b}$ & $204.01 \mathrm{~b}$ & $52.00 \mathrm{~b}$ & $1771 \mathrm{~b}$ & $4145 \mathrm{~b}$ & $29.92 \mathrm{~b}$ \\
\hline $\mathrm{Fe}$ & $10.12 \mathrm{~b}$ & $27.80 \mathrm{ab}$ & $197.50 \mathrm{a}$ & $221.00 \mathrm{a}$ & $60.62 \mathrm{a}$ & $2017 \mathrm{a}$ & $4519 a$ & $30.77 \mathrm{ab}$ \\
\hline $\mathrm{Zn}$ & $11.06 \mathrm{a}$ & $28.31 \mathrm{a}$ & $192.66 \mathrm{a}$ & $216.66 \mathrm{a}$ & $57.93 \mathrm{a}$ & $2088 \mathrm{a}$ & $4344 \mathrm{ab}$ & $32.46 \mathrm{a}$ \\
\hline nano- titanium & ns & 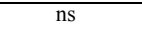 & & ns & & ns & & ns \\
\hline non & $10.35 \mathrm{a}$ & $27.37 \mathrm{a}$ & $188.33 \mathrm{~b}$ & $214.00 \mathrm{a}$ & $54.37 \mathrm{~b}$ & $1980 \mathrm{a}$ & $4055 \mathrm{~b}$ & $32.68 \mathrm{a}$ \\
\hline with & $10.12 \mathrm{a}$ & $28.01 \mathrm{a}$ & $196.66 \mathrm{a}$ & $213.33 \mathrm{a}$ & $59.31 \mathrm{a}$ & $2035 \mathrm{a}$ & $4390 \mathrm{a}$ & $31.64 \mathrm{a}$ \\
\hline $\mathrm{CV} \%$ & 4.89 & 5.99 & 5.68 & 3.14 & 12.72 & 10.68 & 17.58 & 9.32 \\
\hline
\end{tabular}

$\mathrm{SL}=$ spike length $(\mathrm{cm}), \mathrm{TGW}=1000$ grain mass $(\mathrm{g}), \mathrm{DA}=$ days to anthesis, $\mathrm{DM}=$ days to maturity, $\mathrm{CHL}=$ chlorophyll content (SPAD unit), GY= grain yield $\left(\mathrm{Kg} \mathrm{ha}^{-1}\right), \mathrm{SY}=$ straw yield $\left(\mathrm{Kg} \mathrm{ha}^{-1}\right), \mathrm{HI}=$ harvest index (\%). Mean values of the same category followed by different letters are significant at $p \leq 0.05$ level.

Likewise the evaluation of the phenological characteristics i.e. day to anthesis (DA) and day to maturity (DM) showed that application of micronutrients and $\mathrm{nTiO}_{2}$ significantly affected them. It has been documented that plants under optimum condition tend to increase growth period as much as possible which can result in improved leaf photosynthesis, light-use potential and higher yield (Cui et al., 2015). This study showed that nano-fertilizers and nano $\mathrm{TiO}_{2}$ considerably influenced the straw (SY) and grain yield (GY), which corroborate the findings of a great deal of the previous work (Gao et al., 2013; Morteza et al., 2013; Klingenfuss, 2014; Tarafdar et al., 2014). Foliar utilization of micronutrients improved straw yield and grain yield up to $7 \%$ and $16 \%$ over to control, respectively. Moreover, spray of $\mathrm{nTiO}_{2}$ enhanced the straw yield by $8 \%$. A significant increase of grain yield in response to nanofertilizer application statistically improved the harvest index (HI) in comparison with control.

Result of our study suggested that yield component of barley can be positively affected by of $\mathrm{nTiO}_{2}$ and nano chelated micronutrient fertilizers and it can be introduced as a safe nano-nutrient. In plant nanoparticles may adsorb to plant surface and taken up through natural nano or micrometer scale openings. The results of other previous studies demonstrated $\mathrm{nTiO}_{2}$ as an efficient photocatalyst by improving the photosynthetic complexes, and nitrogen metabolism can enhance cell growth as well as fresh and dry mass of plant (Morteza et al.,
2013; Gao et al., 2013; Klingenfuss, 2014; Rezaei et al., 2015; Raliya et al., 2015). However evidence from this study suggested that $\mathrm{nTiO}_{2}$ along with nano-fertilizers can effectively influence both vegetative and reproductive characteristics under supplemental irrigation in semi-arid region. It appears that $\mathrm{nTiO}_{2}$ may play a significant role in activation of defense mechanism and modulating the biosynthesis of phytohormones such as cytokinins and gibberellin (Mandeh et al., 2012).

The correlations between different traits are presented in Table 4. Grain yield observed to be significantly and positively correlated with grain mass (TGW), number of grain per spike (NGS), straw yield (SY) at $99 \%$ confidence level. However peduncle length showed a high negative correlation with yield components. Furthermore a significant correlation was recorded between the number of tiller (NTP), number of the grain per spike (NGS) and chlorophyll content (CHL) with straw yield. Grain yield (GY) also showed a positive correlation at $95 \%$ confidence level with number of days from sowing to anthesis and chlorophyll content. Harvest index (HI) also revealed a very significant and positive association with stem diameter (SD), grain mass (TGW), spike length (SL) and grain yield (Table 4). This trend was confirmed by principle component analysis (PCA). The PCA described a suitable amount of the total variation. The correlation coefficient between any two traits is approximated by the cosine of the angle between their vectors. In the 
Figure 3, the most prominent relations are: a very positive association among grain yield (GY), grain mass (TGW), harvest index (HI), stem diameter (SD) number of the fertile tiller (NFT), spike length (SL); among straw yield (SY), days to maturity (DM); among day to anthesis (DA), chlorophyll content (CHL), number of the grain per spike (NGS) as indicated by the small obtuse angles between their vectors $(\mathrm{r}=\cos 0=+1)$. There was a negative correlation between peduncle length (PL) and plant height (PH) with most of grain yield components (Figure 3 ) as indicated by the near perpendicular vectors $(\mathrm{r}=\cos 180=-1)$.

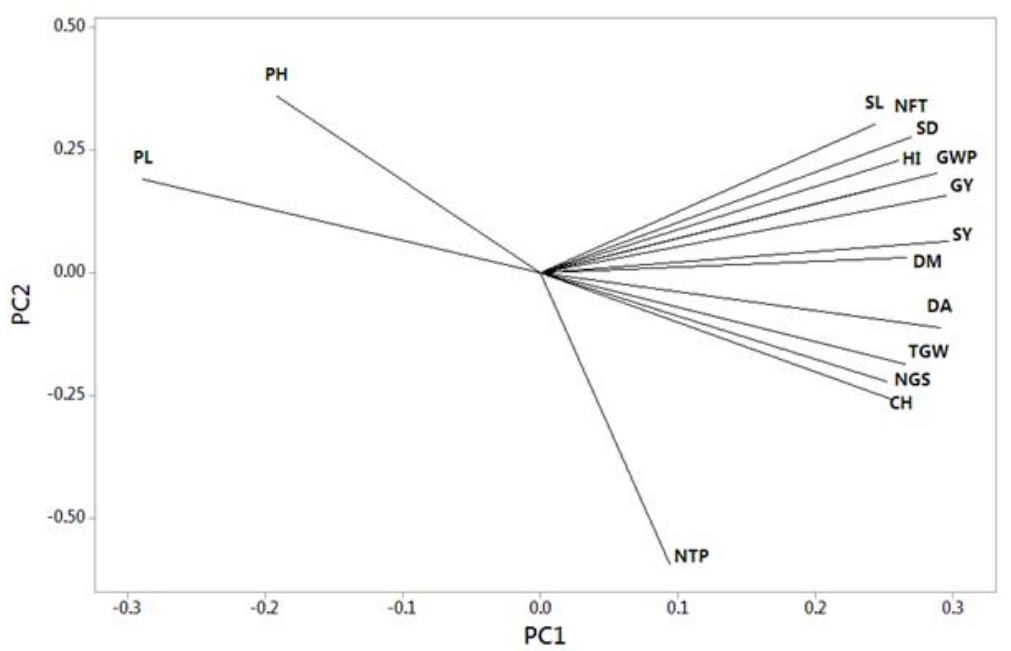

Figure 3: Plot of the first two PCAs showing relation among various agronomical traits of barley.

Table 4: Pearson's correlation coefficients among agronomical traits of barley

\begin{tabular}{|c|c|c|c|c|c|c|c|c|c|c|c|c|c|c|}
\hline & $\mathrm{PH}$ & SD & NTP & NFT & GWP & NGS & PL & SL & TGW & DA & DM & $\mathrm{CH}$ & GY & SY \\
\hline SD & -0.41 & & & & & & & & & & & & & \\
\hline NTP & -0.01 & -0.11 & & & & & & & & & & & & \\
\hline NFT & -0.43 & 0.46 & 0.60 & & & & & & & & & & & \\
\hline GWP & -0.09 & 0.70 & 0.52 & 0.61 & & & & & & & & & & \\
\hline NGS & -0.12 & 0.38 & 0.73 & 0.79 & 0.85 & & & & & & & & & \\
\hline PL & 0.21 & -0.71 & -0.58 & -0.74 & -0.98 & -0.87 & & & & & & & & \\
\hline SL & 0.27 & 0.68 & 0.03 & 0.07 & 0.79 & 0.41 & -0.68 & & & & & & & \\
\hline TGW & -0.29 & 0.74 & 0.57 & 0.76 & 0.90 & 0.75 & -0.96 & 0.59 & & & & & & \\
\hline DA & -0.25 & 0.22 & 0.77 & 0.77 & 0.71 & 0.96 & -0.75 & 0.19 & 0.62 & & & & & \\
\hline DM & -0.26 & 0.70 & 0.09 & 0.47 & 0.77 & 0.72 & -0.73 & 0.63 & 0.55 & 0.65 & & & & \\
\hline $\mathrm{CH}$ & -0.40 & 0.46 & 0.68 & 0.77 & 0.83 & 0.94 & -0.87 & 0.36 & 0.76 & 0.95 & 0.76 & & & \\
\hline GY & -0.11 & 0.62 & 0.63 & 0.73 & 0.98 & 0.93 & -0.99 & 0.67 & 0.91 & 0.81 & 0.75 & 0.89 & & \\
\hline SY & -0.06 & 0.34 & 0.80 & 0.73 & 0.87 & 0.98 & -0.89 & 0.46 & 0.77 & 0.94 & 0.66 & 0.93 & 0.94 & \\
\hline $\mathrm{HI}$ & -0.20 & 0.94 & 0.13 & 0.52 & 0.85 & 0.54 & -0.86 & 0.81 & 0.87 & 0.34 & 0.68 & 0.55 & 0.89 & 0.53 \\
\hline
\end{tabular}

Critical values of correlation $P<0.05$ and $P<0.01$ are 0.79 and 0.90 , respectively. $\mathrm{PH}=$ plant height, $\mathrm{SD}=$ stem diameter $(\mathrm{mm}), \mathrm{NTP}=$ number of tillers per plants, $\mathrm{NFT}=$ number of fertile tillers, $\mathrm{GWP}=$ grain mass per plant, $\mathrm{NGS}=$ number of grain per spike, $\mathrm{PL}=$ peduncle length, $\mathrm{SL}=$ spike length, $\mathrm{TGW}=1000$ grain mass, $\mathrm{DA}=$ days to anthesis, $\mathrm{DM}=$ days to maturity, $\mathrm{CHL}=$ chlorophyll $(\mathrm{SPAD}$ unit), $\mathrm{GY}=$ grain yield, $\mathrm{SY}=$ straw yield, $\mathrm{HI}=$ harvest index. 
In order to know with which combination type of agro-morphological traits the barley would attain high grain yield PCA was performed (Table 5). The Scree plot of the PCA (Figure 4) shows that the first four eigenvalues correspond to the whole percentage of the variance in the dataset. The first four main PCAs are extracted from the complicated components, the total cumulative variance of these five factors amounted to $98 \%$ and these components had eigenvalues $>1$. The PCA simplifies the complex data by transforming the number of associated traits into a smaller number of variables as PCAs. The first principal component (PC1) is grain yield (GY) and yield components that explained $69 \%$ of total variability. The traits, which contributed more positively to $\mathrm{PC} 1$, were grain mass (TGW), days to anthesis (DA), days to maturity (DM), stem diameter (SD), number of fertile tiller (NFT) and straw yield (Table 5). The second principal component (PC2) explains $14 \%$ of total variability and among the property vectors of PC2 vegetative growth parameter like as plant height $(\mathrm{PH})$, spike length (SL) and number of the fertile tiller (NFT) had higher values. The third principal component (PC3) is plant vegetative characters that explain about $11 \%$ of total variability. Among the property vectors of $\mathrm{PC} 3$ plant height $(\mathrm{PH})$, number of the grain per spike (NGS) and number of tiller per plant (NTP) had higher values. The forth principal component (PC4) was related to green area duration (chlorophyll content and days to maturity) and explains about $5 \%$ of total variability (Table 5).

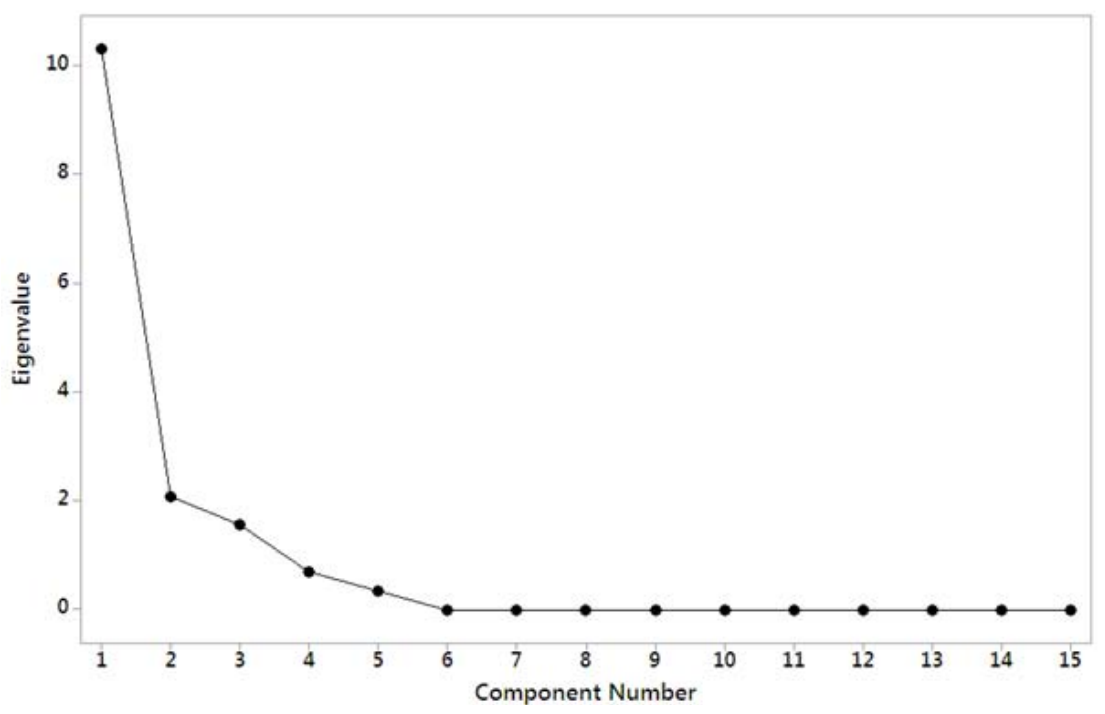

Figure 4: Scree plot showing eigenvalues in response to number of components for the estimated variables of barley. 
Table 5: Loadings of PCA for the estimated traits of barley.

\begin{tabular}{|c|c|c|c|c|}
\hline Variable & PC1 & $\mathrm{PC} 2$ & PC3 & $\mathrm{PC} 4$ \\
\hline $\mathrm{PH}$ & -0.19 & 0.36 & 0.42 & 0.20 \\
\hline SD & 0.26 & 0.23 & -0.17 & -0.42 \\
\hline NTP & 0.10 & -0.59 & 0.33 & -0.04 \\
\hline NFT & 0.27 & 0.28 & -0.18 & 0.17 \\
\hline GWP & 0.29 & 0.20 & -0.03 & -0.07 \\
\hline NGS & 0.25 & -0.22 & 0.32 & 0.35 \\
\hline PL & -0.29 & 0.19 & -0.14 & 0.15 \\
\hline SL & 0.24 & 0.30 & 0.34 & 0.12 \\
\hline TGW & 0.27 & -0.19 & 0.14 & -0.48 \\
\hline DA & 0.29 & -0.11 & -0.21 & 0.07 \\
\hline $\mathrm{DM}$ & 0.27 & 0.03 & -0.21 & 0.44 \\
\hline CHL & 0.26 & -0.26 & -0.23 & 0.37 \\
\hline GY & 0.30 & 0.16 & 0.15 & -0.09 \\
\hline SY & 0.30 & 0.07 & -0.22 & -0.10 \\
\hline $\mathrm{HI}$ & 0.25 & 0.17 & 0.43 & 0.00 \\
\hline Eigenvalue & 10.31 & 2.09 & 1.57 & 0.69 \\
\hline Proportion & 0.69 & 0.14 & 0.11 & 0.05 \\
\hline Cumulative & 0.69 & 0.83 & 0.93 & 0.98 \\
\hline
\end{tabular}

\section{CONCLUSION}

Nanotechnology is the developing technology during recent years and operating in all fields of agriculture. Nano micronutrients fertilizers stand out as one of the most useful materials, due to their high efficiency, functionalities, convenient and easy applications. Although the effects of nanotitanium and nano-chelated micronutrients have been evaluated separately in some studies, here, their combined effects were evaluated on barley under semi-arid region with terminal drought stress. From the present study, it can be concluded that $\mathrm{TiO} 2$ nano particles and micro nutrients nanofertilizers at investigated concentrations does not exhibit any significant phytotoxicity and could increases the chlorophyll content, vegetative growth and yield component of barley under supplemental irrigation condition in semi-arid regions with Mediterranean climates. Contrary to expectations, this study did not find a significant effects of $\mathrm{nTiO}_{2}$ on yield component. This may be due to utilized concentration, time or frequency of application. Additionally, the findings suggest that the foliar application of nano-chelated micronutrients can be resulted in sustainable and high crop production. It can be ascribed to structure and small size of nano-fertilizers which are insoluble in water and the particles are rapidly adsorbed by plant tissue. Rapid delivery of the required elements in different subcellular parts can enhance application efficiency. Foliar application of micro nutrients in semi-arid region can solve the immobilization of element in soil. However, actual movement of nano-particles through the cuticle depends on the nutrient concentration, molecular size, chelating structure, time of application and plant species and environmental condition. Given that nanotechnology industry is growing in a very fast way, there is a crucial urgency to perform further studies about instructions for application of nano-fertilizers, consumption rates, synergistic, antagonistic or neutral interactions and its consequences on the cellular and molecular level. 


\section{ACKNOWLEDGMENTS}

This study was financially supported by Ministry of Science, Research and Technology of Iran and University of Maragheh. We wish to thank Dr. Mojtaba Amini, for his valuable advices regarding the chemical properties of $\mathrm{TiO}_{2}$ nano-particles and critical reading of the manuscript. The authors warmly thank Siavash Solatani and Ali Ezati for their field and technical assistances.

\section{REFERENCES}

Abbas G., Khan M. Q., Jamil M., Tahir M., Hussain F. 2009. Nutrient uptake, growth and yield of wheat (Triticum aestivum) as affected by zinc application rates. International Journal of Agriculture and Biology, 11(4), 389-396.

Arora S., Singh M. 2004. Interaction effect of zinc and nitrogen on growth and yield of barley (Hordeum vulgare L.) on typic ustipsamments. Asian Journal of Plant Sciences, 3(1), 101-103. Doi: 10.3923/ajps.2004.101.103

Batisani N., Yarnal B. 2010. Rainfall variability and trends in semi-arid Botswana: implications for climate change adaptation policy. Applied Geography, 30(4), 483-489. Doi: 10.1016/j.apgeog.2009.10.007

Bihmidine S., Hunter C. T., Johns C. E., Koch K. E., Braun D. M. 2013. Regulation of assimilate import into sink organs: update on molecular drivers of sink strength. Frontiers in plant science, 4. Doi: 10.3389/fpls.2013.00177

Boorboori M. R., Asli E., Tehrani M. M. 2012. Effect of micronutrient application by different methods on yield, morphological traits and grain protein percentage of barley (Hordeum vulgare L.) in greenhouse conditions. Revista Científica UDO Agrícola, 12(1), 128-135.

Bouis H. E. 2003. Micronutrient fortification of plants through plant breeding: can it improve nutrition in man at low cost?. Proceedings of the Nutrition $\begin{array}{llll}\text { Society, } & 62 & \text { (2), 403-411. Doi: }\end{array}$ 10.1079/PNS2003262

Cui Y., Tian Z., Zhang X., Muhammad A., Han H., Jiang D., Cao W., Dai T. 2015. Effect of water deficit during vegetative growth periods on postanthesis photosynthetic capacity and grain yield in winter wheat (Triticum aestivum L.). Acta Physiologiae Plantarum, 37,196-217. Doi: 10.1007/s11738-015-1944-2

DeRosa M. C., Monreal C., Schnitzer M., Walsh R., Sultan Y. 2010. Nanotechnology in fertilizers. Nature nanotechnology, 5(2), 91-91. Doi: 10.1038/nnano. 2010.2
Fahad S., Ahmad M., Akbar Anjum M., Hussain S. 2014. The effect of micronutrients (B, Zn and Fe) foliar application on the growth, flowering and corm production of gladiolus (Gladiolus grandiflorus L.) in calcareous soils. Journal of Agricultural Science and Technology, 16, 16711682.

Faostat. 2013: FAOSTAT. Food and Agricultural Organisation of the United Nations. Available at: http://faostat.fao.org.

Galavi M., Ramroudi M., Tavassoli A. 2012. Effect of micronutrients foliar application on yield and seed oil content of safflower (Carthamus tinctorius). African Journal of Agricultural Research, 7(3), 482-486.

Gao J., Xu G., Qian H., Liu P., Zhao P., Hu Y. 2013. Effects of nano- $\mathrm{TiO}_{2}$ on photosynthetic characteristics of Ulmus elongata seedlings. Environmental Pollution, 176, 63-70. Doi: 10.1016/j.envpol.2013.01.027

Ghasemi-Fasaei R., Ronaghi A. 2008. Interaction of iron with copper, zinc, and manganese in wheat as affected by iron and manganese in a calcareous soil. Journal of Plant Nutrition, 31(5), 839-848. Doi: $10.1080 / 01904160802043148$

Hänsch R., Mendel R. R. 2009. Physiological functions of mineral micronutrients $(\mathrm{Cu}, \mathrm{Zn}, \mathrm{Mn}, \mathrm{Fe}, \mathrm{Ni}, \mathrm{Mo}$, $\mathrm{B}, \mathrm{Cl}$ ). Current opinion in plant biology, 12(3), 259-266. Doi: 10.1016/j.pbi.2009.05.006

Jam E., Sajed K., Ebadi A., Farjaminejad R., Ghasempour F. 2011. Effect of $\mathrm{Fe}$ and $\mathrm{Zn}$ micronutrients spray on grain yield of autumn wheat in Ardabil Region, Iran. Journal of Plant Ecophysiology, 3(2), 101-107.

Klingenfuss F.2014. Testing of $\mathrm{Tio}_{2}$ nanoparticles on wheat and microorganisms in a soil microcosm. Thesis for master of science in ecotoxicology, University of Gothenburg, p. 62.

Mandeh M., Omidi M., Rahaie, M. 2012. In vitro influences of $\mathrm{TiO} 2$ nanoparticles on barley (Hordeum vulgare L.) tissue culture. Biological 
trace element research, 150(1-3), 376-380. Doi: $10.1007 / \mathrm{s} 12011-012-9480-\mathrm{z}$

Marschner H. 2012. Marschner's mineral nutrition of higher plants. P. Marschner (Ed.). Academic press.

Morteza E., Moaveni P., Farahani H. A., Kiyani M. 2013. Study of photosynthetic pigments changes of maize (Zea mays L.) under nano $\mathrm{Tio}_{2}$ spraying at various growth stages. SpringerPlus, 2(1), 1-5. Doi: 10.1186/2193-1801-2-247

Naderi M. R., Danesh-Shahraki A. 2013. Nanofertilizers and their roles in sustainable agriculture. International Journal of Agriculture and Crop Sciences, 5(19), 2229-2232.

Nair R., Varghese S. H., Nair B. G., Maekawa T., Yoshida Y., Kumar, D. S. 2010. Nanoparticulate material delivery to plants. Plant science, 179(3), 154-163. Doi: 10.1016/j.plantsci.2010.04.012

Raliya R., Biswas P., Tarafdar, J. C. 2015. $\mathrm{TiO}_{2}$ nanoparticle biosynthesis and its physiological effect on mung bean (Vigna radiata L.). Biotechnology Reports, 5, 22-26. Doi: 10.1016/j.btre.2014.10.009

Rameshaiah G. N., Jpallavi S. 2015. Nano fertilizers and nano sensors-an attempt for developing smart agriculture. International Journal of Engineering Research and General Science, 3 (1): 314-320,

Rezaei F., Moaveni P., Mozafari H. 2015. Effect of different concentrations and time of nano $\mathrm{Tio}_{2}$ spraying on quantitative and qualitative yield of soybean (Glycine $\max$ L.) at Shahr-e-Qods, Iran. Biological Forum, 7(1): 957 -964.

Ryan J., Sommer R., Ibrikci H. 2012. Fertilizer best management practices: A perspective from the dryland West Asia-North Africa region. Journal of Agronomy and Crop Science, 198(1), 57-67. Doi: 10.1111/j.1439-037X.2011.00488.X

Saalbach I., Mora-Ramírez I., Weichert N., Andersch F., Guild G., Wieser H., Koehler P., Stangoulis J., Kumlehn J., Weschke W., Weber H. 2014. Increased grain yield and micronutrient concentration in transgenic winter wheat by ectopic expression of a barley sucrose transporter. Journal of Cereal Science, 60(1), 75-81. Doi: 10.1016/j.jcs.2014.01.017

Song U., Shin M., Lee G., Roh J., Kim Y., Lee E. J. 2013. Functional analysis of $\mathrm{TiO}_{2}$ nanoparticle toxicity in three plant species. Biological trace element research, 155(1), 93-103. Doi: 10.1007/s12011-013-9765-X

Tarafdar J. C., Raliya R., Mahawar H., Rathore I. 2014. Development of zinc nanofertilizer to enhance crop production in pearl millet (Pennisetum americanum). Agricultural Research, 3(3), 257262. Doi: $10.1007 / \mathrm{s} 40003-014-0113-y$

Yang J., Zhang J., Wang Z., Zhu Q. 2003. Hormones in the grains in relation to sink strength and postanthesis development of spikelets in rice. Plant Growth Regulation, 41(3), 185-195. Doi: 10.1023/B:GROW.0000007503.95391.38

Zhang F., Wang R., Xiao Q., Wang Y., Zhang, J. 2006. Effects of slow/controlled-release fertilizer cemented and coated by nano-materials on biology. II. Effects of slow/controlled-release fertilizer cemented and coated by nano-materials on plants. Nanoscience, 11, 18-26. 